\title{
How Allogeneic Hematopoietic Stem Cell Transplantation has Evolved Over Time: 30-Years' Experience at a Single Institution
}

\author{
Transplantação Alogénica de Medula Óssea: Evolução \\ ao Longo de 30 Anos na Experiência de um Centro
}

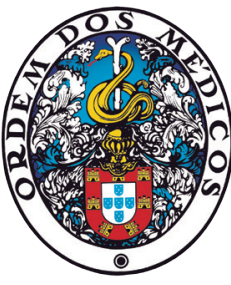

\author{
Manuel ABECASIS $\square^{1}$, Nuno MIRANDA ${ }^{1}$, Isabelina FERREIRA ${ }^{1}$, Gilda TEIXEIRA ${ }^{1}$, Filipa MOITA ${ }^{1}$, \\ Fernando Leal da COSTA ${ }^{1}$, Maria João GUTIERREZ ${ }^{1}$, Carla ESPADINHA ${ }^{1}$, Susana ESTEVES ${ }^{2}$ \\ Acta Med Port 2020 Feb;33(2):116-123 - https://doi.org/10.20344/amp.11768
}

ABSTRACT

Introduction: Allogeneic stem cell transplantation is an established procedure for a variety of diseases of the hematopoietic system. Our transplant program started in 1987 and since then advances have been made in the care of patients undergoing transplantation. We conducted a study to evaluate whether the changes implemented over time have improved the outcomes of transplantation.

Material and Methods: We analyzed changes in patients, cell source, transplantation and outcome among 682 consecutive patients receiving their first transplant between 1987 and 2016. We compared overall survival, progression-free survival, the incidence of nonrelapse mortality and relapse in 10-year cohorts over the three decades of the study.

Results: The median age of transplanted patients, the use of peripheral blood and unrelated donors all increased very significantly. There was an increase in the number of high-risk patients when comparing the first decade with the two subsequent ones. The 3-year non-relapse mortality decreased significantly from $29 \%$ to $20 \%(p=0.045)$, while the overall survival, progression free survival and cumulative incidence of relapse remained stable.

Discussion: Allogeneic hematopoietic stem cell transplantation has evolved considerably since its introduction in clinical practice. In the present study, we evaluated how these changes affected our practice along 30 years of activity and compared the results with those published in the literature.

Conclusion: Despite increasing age, higher risk patients and the increasing use of unrelated donors our results show a continuous significantly reduced non-relapse mortality, with stable overall survival, progression free survival and relapse rate.

Keywords: Hematopoietic Stem Cell Transplantation; Portugal

\section{RESUMO}

Introdução: A transplantação alogénica de células hematopoiéticas é utilizada regularmente no tratamento de uma grande variedade de doenças hematológicas. O nosso programa de transplantação teve início em 1987 e desde então têm sido numerosos os avanços nesta área. Este estudo foi conduzido para avaliar se as alterações introduzidas ao longo de 30 anos melhoraram os resultados obtidos. Material e Métodos: Analisámos os resultados numa população de 682 doentes submetidos consecutivamente a um primeiro transplante alogénico entre 1987 e 2016. Para tal, os doentes foram divididos em intervalos de 10 anos e comparámos a sobrevida global, a sobrevida livre de progressão, a mortalidade não associada a recaída e as recaídas em cada década do estudo.

Resultados: A mediana de idades dos doentes transplantados, a utilização de células progenitoras provenientes do sangue periférico e a transplantação com dadores não familiares aumentaram muito significativamente ao longo do estudo. Verificou-se, comparativamente com a primeira década, um aumento do número de doentes de alto risco nas duas décadas subsequentes. A mortalidade não relacionada com recidiva, avaliada aos três anos pós-transplante, diminuiu significativamente de $29 \%$ para $20 \%(p=0,045)$, mantendo-se estáveis a sobrevida global e a sobrevida livre de progressão, assim como a incidência cumulativa de recaídas.

Discussão: A transplantação alogénica hematopoiética tem evoluído consideravelmente desde a sua introdução na prática clínica. No presente trabalho são avaliados os reflexos dessa evolução ao longo de 30 anos sendo analisados os resultados obtidos e comparados com os referidos na literatura.

Conclusão: Apesar das características mais desfavoráveis verificadas ao longo das três décadas (doentes mais idosos, doenças de risco mais elevado, aumento do número de dadores não familiares) foi possível reduzir significativamente a mortalidade associada ao procedimento, mantendo-se estáveis a sobrevida global e livre de progressão, assim como a incidência de recaídas.

Palavras-chave: Portugal; Transplante de Células-Tronco Hematopoéticas

\section{INTRODUCTION}

A wide variety of hematopoietic and non-hematopoietic diseases, ranging from hematologic malignancies to metabolic disorders and congenital or acquired bone marrow failures are successfully treated by allogeneic hematopoietic stem cell transplantation (HSCT) ${ }^{1-4}$ In the early 1970 s, toxicity from conditioning, infections, and graft-versus-host disease (GvHD) were associated with a significant risk of

death, such that its application was the subject of some criticism. ${ }^{5}$ Over the past 50 years, advances in HLA-typing with better matching, better prophylaxis and treatment of frequent complications plus the introduction of reduced intensity conditioning regimens all have contributed to improve the results of HSCT, making it a safer procedure to be offered to a wider group of patients. ${ }^{6-8}$

\footnotetext{
1. Bone Marrow Transplantation Service. Instituto Português de Oncologia de Lisboa Francisco Gentil. Lisboa. Portugal.

2. Clinical Research Unit. Instituto Português de Oncologia de Lisboa Francisco Gentil. Lisboa. Portugal.

$\triangle$ Autor correspondente: Manuel Abecasis. mabecasis@ipolisboa.min-saude.pt

Recebido: 03 de janeiro de 2019 - Aceite: 26 de agosto de 2019 | Copyright $\odot$ Ordem dos Médicos 2020
} 
The purpose of this study was to compare transplant characteristics and results obtained over 30 years, since the beginning of our combined adult and pediatric transplant program in May 1987, the first to be conducted in Portugal and the longest in permanent activity.

\section{MATERIAL AND METHODS Patients}

This retrospective study included 682 consecutive patients who underwent their first allogeneic HSCT between 1987 and 2016 . The study was divided into three time periods (28/05/87 to $27 / 05 / 97 ; 28 / 05 / 97$ to $27 / 05 / 07 ; 28 / 05 / 07$ to $31 / 05 / 16)$. Data for this analysis were obtained from our patient database and collected from 28 May 1987 to 31 May 2016. The cut-off date for analysis was 31 May 2017. Survivors were censored at the date of last follow-up. Patients and donors gave permission for the use of their data and the study was approved by the institutional review board.

\section{Transplantation techniques}

All patients received a conditioning regimen followed by infusion of donor cells, mostly as inpatients in single rooms with HEPA filtered air. Although these regimens varied, the myeloablative conditioning (MAC) generally contained highdose cyclophosphamide with busulfan or 12.0 to $13.2 \mathrm{~Gy}$ of total body irradiation (TBI). Reduced intensity regimens (RIC), introduced over the last two decades, were defined as in Bacigalupo et $a^{9}{ }^{9}$ and usually contained fludarabine with either $2 \mathrm{~Gy} \mathrm{TBI}$, low dose busulfan or melphalan. Patients with acute leukemia $(A L)$ in first complete remission (CR1), chronic myeloid leukemia (CML) in first chronic phase, aplastic anemia and non-malignant conditions were considered standard risk. ${ }^{10}$ Patients with AL beyond CR1, CML beyond the first chronic phase, lymphomas and all malignancies in partial remission, progression or relapse were included in the high risk group. GvHD prophylaxis was with calcineurin inhibitors associated with methotrexate or mycophenolate mofetil, in vivo T cell depletion with ATG was added when using unrelated donors. Patients with an HLA C mismatch were given alemtuzumab instead of ATG to decrease the risk of graft rejection. ${ }^{11,12}$ Prophylaxis against infections was with acyclovir, co-trimoxazole, oral quinolone and an azol antifungal agent. For cytomegalovirus (CMV) reactivation (on the basis of the viral pp65 antigen or plasma DNA testing) preemptive therapy with ganciclovir was introduced in 1989. Since 1995, all patients received filgrastim from day +5 or +7 until the absolute neutrophil count reached $0.5 \times 10 \% / \mathrm{L}$. Routine veno-occlusive prophylaxis was not used.

\section{Outcome measures}

Outcome measures included overall survival (OS), progression free survival (PFS), non-relapse mortality (NRM), GVHD related mortality, incidence of second malignancies and incidence of relapse. OS was defined as the time from the first allograft to death from any cause and PFS as the time from the first allograft to the first disease progression/ relapse or death from any cause. NRM was defined as death after transplantation that was not preceded by a recurrence of the underlying disease. Data on these outcome measures reflect events as of the date of the last follow-up before the database was locked on 31 May, 2017.

\section{Statistical analyses}

We conducted a descriptive analysis of the clinical, demographic and transplant characteristics using absolute and relative frequencies for categorical variables and the median and range for quantitative variables. Variable comparison between the three transplant periods was carried out using the Pearson's chi-square test for categorical variables. In cases where an asymptotic test was not appropriate (cells with expected frequency below 5 ) we conducted a chi-squared test with simulated $p$-value based on 2000 replicates. For quantitative data, comparisons were performed using the Kruskal-Wallis test.

OS and PFS were calculated using the Kaplan-Meier method and the log-rank test for group comparison. Nonrelapse mortality, GVHD related mortality, incidence of secondary malignancies and incidence of relapse were calculated using the cumulative incidence procedure for competing risk models and the Gray test for group comparison. All tests were two-sided and a significance level of $5 \%$ was considered. All analyses were done using the R package. ${ }^{13}$

\section{RESULTS}

\section{Patients and transplant characteristics}

During the study period 682 consecutive patients received a first allogeneic transplant. Patient disease and transplantation characteristics are detailed in Table 1. When compared across the three decades, the median age of pediatric patients remained stable $(p=0.376)$ as opposed to adult patients whose age increased significantly over the study period $(p<0.001)$.

The percentage of unrelated donations increased significantly over the three decades; as for the source of stem cells, bone marrow was the preferred source during the first decade, but decreased over the two subsequent periods ( $p$ $<0.001)$.

Umbilical cord blood was started in 1994 and a total of 38 patients $(6 \%)$ were transplanted with this source during the time period of the study, either from an unrelated donor or from family-directed cord blood. ${ }^{14}$

Conditioning regimens varied according to transplant period (Table 1). The percentage of patients given a MAC conditioning decreased significantly from $87 \%$ the first decade to $72 \%$ in the last decade $(p<0.001)$.

The use of ATG in the conditioning regimen increased significantly over the study period $(p<0.001)$.

Since November 2014, 10 patients (eight Hodgkin's disease and two AML) were given unmanipulated haploidentical transplants. Hodgkin's disease patients were conditioned with the Baltimore protocol ${ }^{15}$ and the others with the Genoa protocol. ${ }^{16}$ The proportion of patients with non-malignant conditions (aplastic anemia, hemoglobinopathies, 
Table 1 - Patient and first allotransplant characteristics by decade

\begin{tabular}{|c|c|c|c|c|c|}
\hline Characteristic, n(\%) & All & $\begin{array}{c}1^{\text {st }} \text { decade } \\
1987-1997\end{array}$ & $\begin{array}{c}2^{\text {nd }} \text { decade } \\
1997-2007\end{array}$ & $\begin{array}{c}3^{\text {rd }} \text { decade } \\
2007-2016\end{array}$ & $\boldsymbol{p}^{1}$ \\
\hline $\begin{array}{l}\text { No. of first allotransplants } \\
\text { Pediatric patients } \\
\text { Adult patients }\end{array}$ & $\begin{array}{l}682 \\
271 \\
411\end{array}$ & $\begin{array}{c}164 \\
72 \\
92\end{array}$ & $\begin{array}{c}232 \\
94 \\
138\end{array}$ & $\begin{array}{l}286 \\
105 \\
181\end{array}$ & --- \\
\hline $\begin{array}{l}\text { Patient age (years), Median (range } \\
\text { All patients } \\
\text { Pediatric patients } \\
\text { Adult patients }\end{array}$ & $\begin{array}{l}26(0.3-67) \\
8(0.3-18) \\
38(19-67)\end{array}$ & $\begin{array}{l}22(0.5-53) \\
8(0.5-18) \\
31(19-53)\end{array}$ & $\begin{array}{l}26(0.3-58) \\
7(0.3-17) \\
37(20-58)\end{array}$ & $\begin{array}{l}33(0.4-67) \\
8(0.4-18) \\
42(19-67)\end{array}$ & $\begin{array}{r}<0.001 \\
0.376 \\
<0.001\end{array}$ \\
\hline $\begin{array}{l}\text { Patient gender } \\
\text { Female } \\
\text { Male }\end{array}$ & $\begin{array}{l}292(43 \%) \\
390(57 \%)\end{array}$ & $\begin{array}{c}59(36 \%) \\
105(64 \%)\end{array}$ & $\begin{array}{c}98(42 \%) \\
134(58 \%)\end{array}$ & $\begin{array}{l}135(47 \%) \\
151(53 \%)\end{array}$ & 0.067 \\
\hline $\begin{array}{l}\text { Diagnosis } \\
\text { Myeloid malignancies } \\
\text { AML } \\
\text { CML } \\
\text { MDS/CMML } \\
\text { MPN } \\
\text { Other }{ }^{2} \\
\text { Lymphoid malignancies } \\
\text { ALL } \\
\text { Lymphoma } \\
\text { CLL } \\
\text { MM } \\
\text { Other }{ }^{3} \\
\text { Bone marrow aplasia } \\
\text { Immunodeficiency disorders } \\
\text { Hemoglobinopathies } \\
\text { Metabolic disorders } \\
\text { Other }\end{array}$ & $\begin{array}{c}339(50 \%) \\
187(55 \%) \\
96(28 \%) \\
36(11 \%) \\
2(1 \%) \\
18(5 \%) \\
242(35 \%) \\
152(63 \%) \\
66(27 \%) \\
11(5 \%) \\
8(3 \%) \\
5(2 \%) \\
63(9 \%) \\
19(3 \%) \\
11(2 \%) \\
7(1 \%) \\
1(<1 \%)\end{array}$ & $\begin{array}{c}92(56 \%) \\
39(42 \%) \\
46(50 \%) \\
5(5 \%) \\
1(1 \%) \\
1(1 \%) \\
47(29 \%) \\
39(83 \%) \\
3(6 \%) \\
2(4 \%) \\
1(2 \%) \\
2(4 \%) \\
21(13 \%) \\
1(1 \%) \\
1(1 \%) \\
2(1 \%) \\
0\end{array}$ & $\begin{array}{c}111(48 \%) \\
52(47 \%) \\
39(35 \%) \\
13(12 \%) \\
1(1 \%) \\
6(5 \%) \\
97(42 \%) \\
66(68 \%) \\
23(24 \%) \\
3(3 \%) \\
3(3 \%) \\
2(2 \%) \\
13(6 \%) \\
3(1 \%) \\
4(2 \%) \\
3(1 \%) \\
1(<4 \%)\end{array}$ & $\begin{array}{c}136(48 \%) \\
96(71 \%) \\
11(8 \%) \\
18(13 \%) \\
0 \\
11(8 \%) \\
98(34 \%) \\
47(48 \%) \\
40(41 \%) \\
6(6 \%) \\
4(4 \%) \\
1(1 \%) \\
29(10 \%) \\
15(5 \%) \\
6(2 \%) \\
2(1 \%) \\
0\end{array}$ & 0.001 \\
\hline $\begin{array}{l}\text { Disease status } \\
\text { High risk } \\
\text { Standard risk }\end{array}$ & $\begin{array}{l}314(46 \%) \\
368(54 \%)\end{array}$ & $\begin{array}{c}62(38 \%) \\
102(62 \%)\end{array}$ & $\begin{array}{l}120(52 \%) \\
112(48 \%)\end{array}$ & $\begin{array}{l}132(46 \%) \\
154(54 \%)\end{array}$ & 0.024 \\
\hline $\begin{array}{l}\text { Donor type } \\
\text { Related } \\
\text { Unrelated } \\
\text { HLA matching } \\
\text { Matched } \\
\text { Other }\end{array}$ & $\begin{array}{l}445(65 \%) \\
237(35 \%) \\
105(44 \%) \\
132(56 \%))\end{array}$ & $\begin{array}{c}160(98 \%) \\
4(2 \%) \\
2(50 \%) \\
2(50 \%)\end{array}$ & $\begin{array}{l}166(72 \%) \\
66(28 \%) \\
28(42 \%) \\
38(58 \%)\end{array}$ & $\begin{array}{l}119(42 \%) \\
167(58 \%) \\
77(46 \%) \\
90(54 \%)\end{array}$ & $<0.001$ \\
\hline $\begin{array}{l}\text { Stem cell source } \\
\text { Bone marrow } \\
\text { PBSC } \\
\text { CB }\end{array}$ & $\begin{array}{c}325(48 \%) \\
319(47 \%) \\
38(6 \%)\end{array}$ & $\begin{array}{l}156(95 \%) \\
2(1 \%) \\
6(4 \%)\end{array}$ & $\begin{array}{c}63(27 \%) \\
148(64 \%) \\
21(9 \%)\end{array}$ & $\begin{array}{c}106(37 \%) \\
169(59 \%) \\
11(4 \%)\end{array}$ & $<0.001$ \\
\hline $\begin{array}{l}\text { Conditioning regimen } \\
\text { Myeloablative } \\
\text { Reduced-intensity conditioning }\end{array}$ & $\begin{array}{l}532(78 \%) \\
149(22 \%)\end{array}$ & $\begin{array}{c}143(87 \%) \\
21(13 \%)\end{array}$ & $\begin{array}{c}185(80 \%) \\
47(20 \%)\end{array}$ & $\begin{array}{c}204(72 \%) \\
81(28 \%)\end{array}$ & $<0.001$ \\
\hline $\begin{array}{l}\text { TBI-based conditioning } \\
\text { No } \\
\text { Yes }\end{array}$ & $\begin{array}{l}541(79 \%) \\
141(21 \%)\end{array}$ & $\begin{array}{l}138(84 \%) \\
26(16 \%)\end{array}$ & $\begin{array}{l}189(81 \%) \\
43(19 \%)\end{array}$ & $\begin{array}{l}214(75 \%) \\
72(25 \%)\end{array}$ & 0.039 \\
\hline $\begin{array}{l}\text { ATG-based conditioning } \\
\text { No } \\
\text { Yes }\end{array}$ & $\begin{array}{l}484(71 \%) \\
198(29 \%)\end{array}$ & $\begin{array}{c}152(93 \%) \\
12(7 \%)\end{array}$ & $\begin{array}{l}170(73 \%) \\
62(27 \%)\end{array}$ & $\begin{array}{l}162(57 \%) \\
124(43 \%)\end{array}$ & $<0.001$ \\
\hline
\end{tabular}

${ }^{1}$ Overall comparison of the three transplant periods;

${ }^{2}$ Other myeloid malignancies includes myelofibrosis $(n=10)$, undifferentiated $A L(n=6)$ and dendritic cell leukemia $(n=2)$

${ }^{3}$ Other lymphoid malignancies includes Burkitt lymphoma $(n=4)$ and plasma cell leukemia $(n=1)$

${ }^{4}$ Missing in one patient who received first allotransplant in the period of 2007-2016.

AML: acute myeloid leukemia; CML: chronic myeloid leukemia; MDS: myelodysplastic syndrome; CMML: chronic myelo monocytic leukemia; MPN: myeloproliferative neoplasm; ALL: acute lymphoblastic leukemia; CLL: chronic lymphocytic leukemia; MM: multiple myeloma; PBSC: peripheral blood stem cells; CB: cord blood; TBI: total body irradiation; ATG: antithymocyte globulin 
inborn errors of metabolism, osteopetrosis, hereditary bone marrow failure syndromes, primary immunodeficiency syndromes) remained stable over the three decades, accounting for $15 \%$ of the total number of transplants. Furthermore, a shift in indications for HSCT in hematologic malignancies, away from CML and ALL and towards AML and lymphomas, could be observed.

With regards to disease status at transplantation there was a significant rise of high-risk patients being transplanted, from the first to the subsequent decades $(p=0.024)$.

\section{Clinical outcomes}

The median follow-up for surviving patients in first decade was 23 years, in the second 13 years and in the last decade 3.5 years. Of the 682 patients, $45 \%$ died and $55 \%$ are still alive at the time of last follow-up with a 3-year OS of $59 \%$. The OS at 3-years for the patients transplanted with a related donor was $60 \%$ and for those who had an unrelated transplant was $59 \%$ ( $p=0.643$ ) (Fig. 1A).

Among those receiving an unrelated transplant, 105 had an HLA identical match (number of alleles tested 6, 8 or 10, depending on the time frame of the transplant), 110 had a one allele mismatched donor and 22 a donor with more than one mismatch. The 3-year OS for the latter patients was significantly worse than for the other two groups (36\% versus $57 \%$ and $65 \%$ respectively, $p=0.036$ ) (Fig. 1B).

The 3-year OS in the decade 1897 - 1997 was 58\%, $55 \%$ in the second decade and rose to $64 \%$ in the last decade with no significant differences among the three time periods (Fig. 1C). The PFS at three years in the first period was $51 \%, 49 \%$ in the second period with a trend towards better results in the third period $(56 \%)(p=0.124)$.

CML patients transplanted in the last decade do not seem to have a worse survival when compared to those treated in previous decades (Fig. 1D).

The day 100 NRM was $12 \%$ on each of the first two decades with a non-significant decrease to $9 \%$ in the last decade of the study.

When comparing the 3-year cumulative incidence of NRM among the three decades there was a significant improvement in the results observed over the time period of the study, being respectively $28 \%, 24 \%$ and $19 \%$ over each of the 3 time periods ( $p=0.045$ ) (Fig. 1E).

The 3-year cumulative mortality associated with GVHD as a whole (acute and chronic) was $8.5 \%$ in the first decade, $11.2 \%$ in the second decade and $7.6 \%$ in the last period ( $p$ $=0.320$, Fig. 1F).

The cumulative incidence of relapse/progression at 3 -years was $27 \%$. It remained relatively stable throughout the three decades (Fig. 2A).

We could not demonstrate any significant difference between RIC and MAC conditioning regarding the cumulative incidence of relapse (Fig. 2B).

The cumulative incidence of secondary malignancies in the overall population rose from $0.95 \%$ at 3 years to $4.42 \%$ at 15 years, with a similar incidence in the first and second decades (Fig. 3). There were 10 cases of basal cell carcinoma, four head and neck cancers, four melanomas, three breast cancers, two thyroid cancers and one each of bladder carcinoma and liver adenocarcinoma. One further patient developed a diffuse large B cell lymphoma and another, originally transplanted for severe aplastic anemia, developed acute myeloid leukemia of donor cell origin.

\section{Causes of death}

Three hundred and ten patients died during the period of the study and the causes of death are detailed in Table 2. Relapse accounted for 138 of the deaths, and 169 were due to HSCT related complications, including four graft rejections. With longer follow-up, other causes of death were observed, such as cardiovascular disorders (one myocardial infarction, three strokes) and other malignancies (four oral cavity/pharynx, one bladder carcinoma, one hepatic adenocarcinoma, one Ewing sarcoma and one inoperable cavernous sinus meningioma).

There were two suicides among our patients, and one fatal road traffic accident.

\section{DISCUSSION}

During the past decades HSCT has changed considerably in terms of clinical diagnosis, choice of donor, stem cell source, conditioning regimens, and several other measures destined to reduce and treat transplant related complications. Although we have been running an autologous and allogeneic transplant program, for both pediatric and adult patients, the present study only includes consecutively transplanted patients receiving a first allogeneic transplant, from May 1987 to May 2016.

The entire population is composed of 682 patients and all of them, with the exception of three cases lost to followup, were followed-up until the time of death or the last yearly visit since transplantation, allowing us to have a broader view of the long term outcome of our patient population.

The total number of transplanted patients increased in each decade and they tended to be transplanted with more advanced disease. The adult patients' age increased significantly $(p<0.001)$. Peripheral blood stem cells became the preferred stem cell source for transplant (although in the last decade we saw an increase in the number of bone marrow donations) and in the last decade unrelated donors clearly outnumbered family donors $(p<0.001)$. This is probably related to the success of the donor registries in recruiting more donors, (the Portuguese registry has increased its number of donors from 1500 to nearly 400000 over the last 15 years) and to advances in HLA typing allowing for a better selection of unrelated donors. This may contribute to the improved survival rate reported in several studies, with similar outcomes among transplantations from HLA matched related or 10/10 allele-matched unrelated donors, or even 9/10 unrelated donors, just like our experience in this study. ${ }^{17-19}$ The 3-year OS of our patients transplanted with an unrelated donor was $59 \%$, which is identical to the $60 \%$ observed in those transplanted with a related donor; no difference in OS was seen between patients trans- 
A
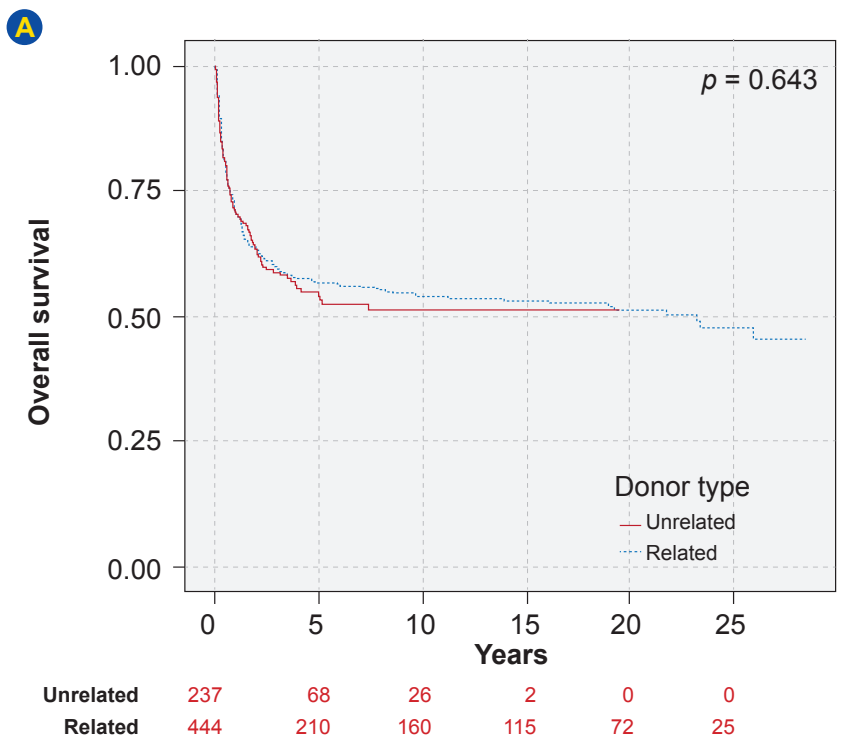

C

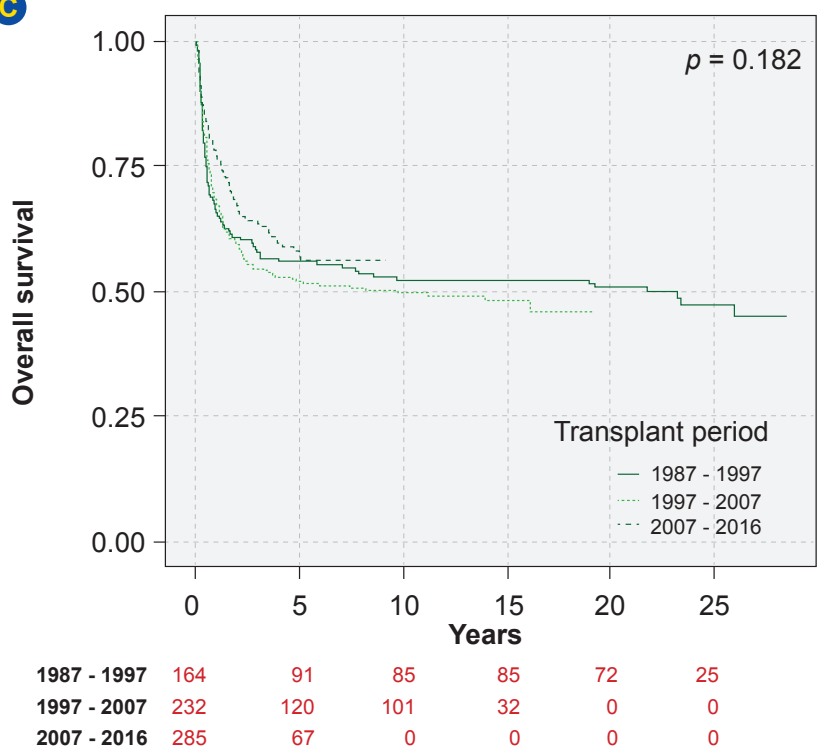

E

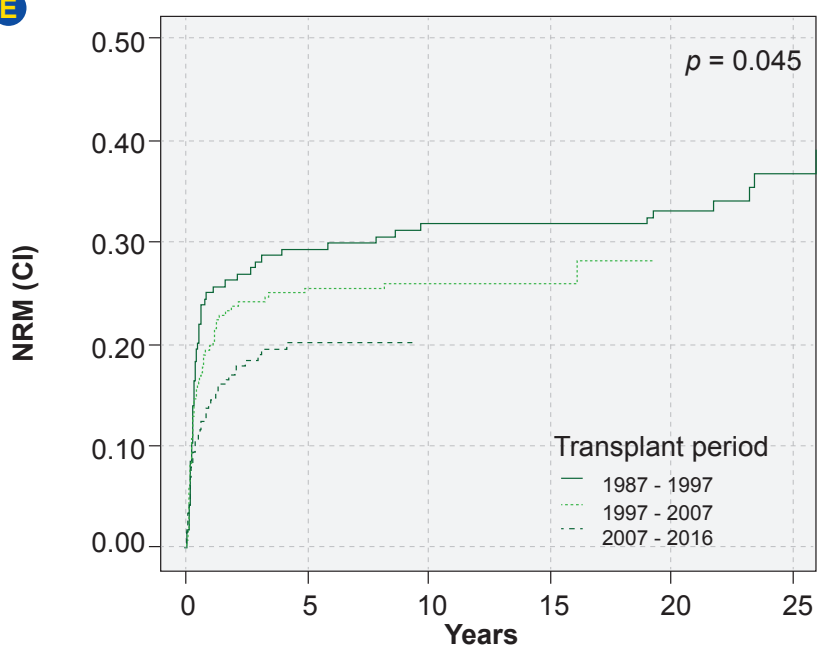

B

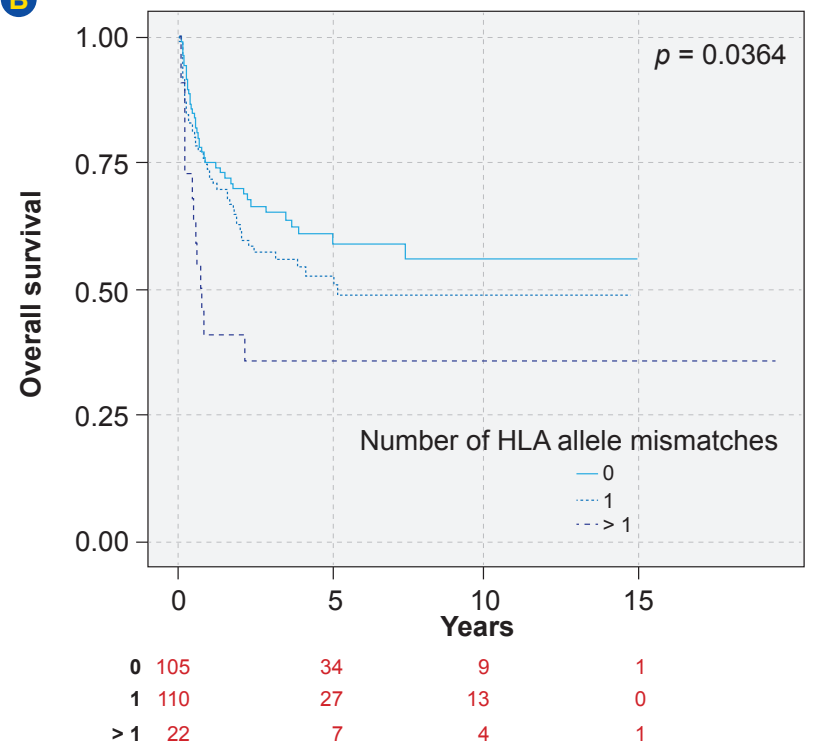

(D)

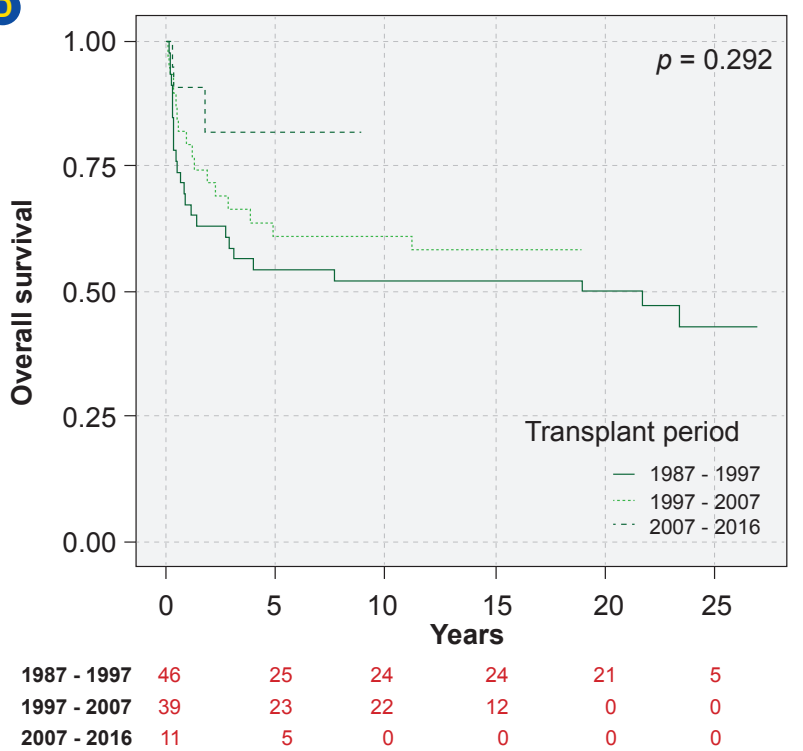

F

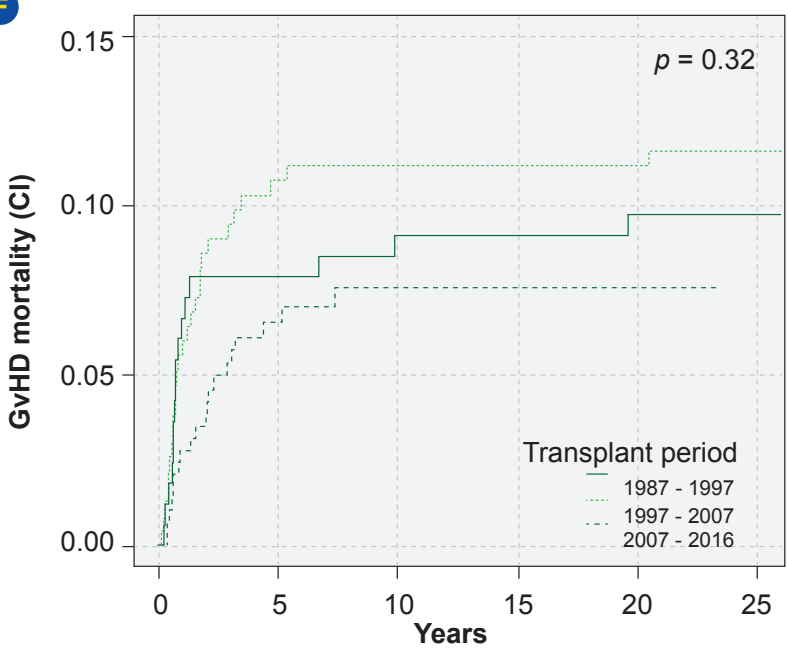

Figure 1 - Outcomes after allotransplant. (A) Overall survival by donor type in overall sample. (B) Overall survival by HLA allele mismatch in unrelated donor transplants. (C) Overall survival by transplant period in overall sample. (D) Overall survival by transplant period in CML patients. (E) Cumulative incidence of Non-Relapse Mortality by transplant period in overall sample. (F) Cumulative incidence of GvHD mortality by transplant period in overall sample. Numbers in red refer to "Numbers at risk". 
A

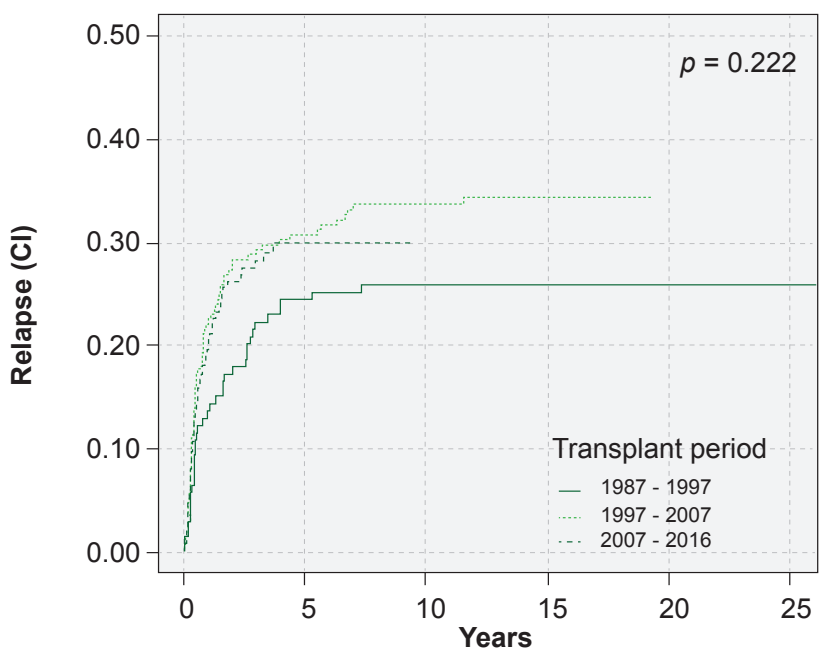

B

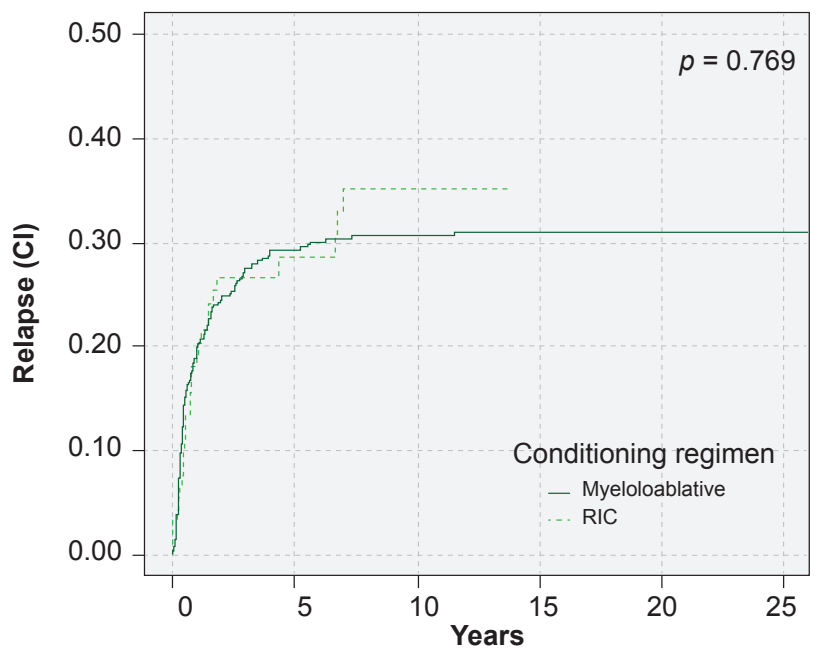

Figure 2 - (A) Cumulative incidence of relapse by transplant period in patients with hematological malignancies. (B) Cumulative incidence of relapse by conditioning regimen in patients with hematological malignancies.

planted with an HLA identical unrelated donor and those whose donors had a single HLA mismatch. The outcome for $9 / 10$ unrelated transplants is still a matter of controversy with some authors reporting inferior OS when compared to $10 / 10$ unrelated transplants and others reporting similar results in terms of OS, GvHD, TRM and relapse. ${ }^{17-20}$ Differences in conditioning regimens (use of ATG, MAC versus RIC), GvHD prophylaxis, disease diagnosis and stage at transplant are possible explanations for this discrepancy. ${ }^{17-21}$

Major developments in hemato-oncology translated into variations in the disease profile of the patients treated in our program. Presently, CML patients needing a transplant are those who fail tyrosine kinase inhibitors (TKIs) treatment or present in accelerated or blast crisis, with a decline of patients transplanted for CML. This may start to increase as the prevalence of CML increases, and patients resistant to TKls will likely require HSCT. ${ }^{22-24}$ One would expect a worse survival for these patients, but our preliminary results indicate a similar PFS for patients transplanted in the TKI era. These results are in keeping with recent reports. ${ }^{22-24}$ We have also seen a reduction in the number of patients transplanted for ALL, particularly children, reflecting the improvement in the modern chemotherapy protocols and the introduction of the minimal residual disease concept, whose negativity has become the target of the more recent protocols. ${ }^{25}$ Conversely, the number of transplants for AML patients rose significantly and this is probably multifactorial, namely better supportive care during induction chemotherapy allowing for more patients being brought to transplant, better definition of patients who may benefit from a transplant, acceptance of older patients in our program and the availability of better well matched unrelated donors. Although the numbers are small, we also saw an increase in the numbers of patients transplanted for lymphomas, from $6 \%$ of all lymphoid malignancies in the first decade to $41 \%$ in the third decade. This is in line with the recent trend observed in the most recent EBMT survey analysis. ${ }^{26}$
Even though the number of patients given MAC conditioning was significantly reduced over time $(p<0.001)$, with a consequent increase in patients given RIC conditioning, this was only reflected in a small, non-significant increase in the relapse rate of hematologic malignancies over the study period. These results are not in agreement with previous reports but different characteristics among the patients treated in different studies may explain different outcomes. ${ }^{8}$

The causes of death varied in the study period. In the first decade, disease relapse and HSCT related causes accounted, respectively, for $31 \%$ and $69 \%$ of the deaths, whereas in the last decade each of these causes was responsible for $51 \%$ and $49 \%$ of the deaths.

The 3-year OS remained stable over the study period. However, the characteristics of the population treated changed, with significantly more unrelated transplants and older patients being treated. Still, the cumulative incidence of GvHD-related mortality was not significantly different in the three decades; however, the NRM due to other

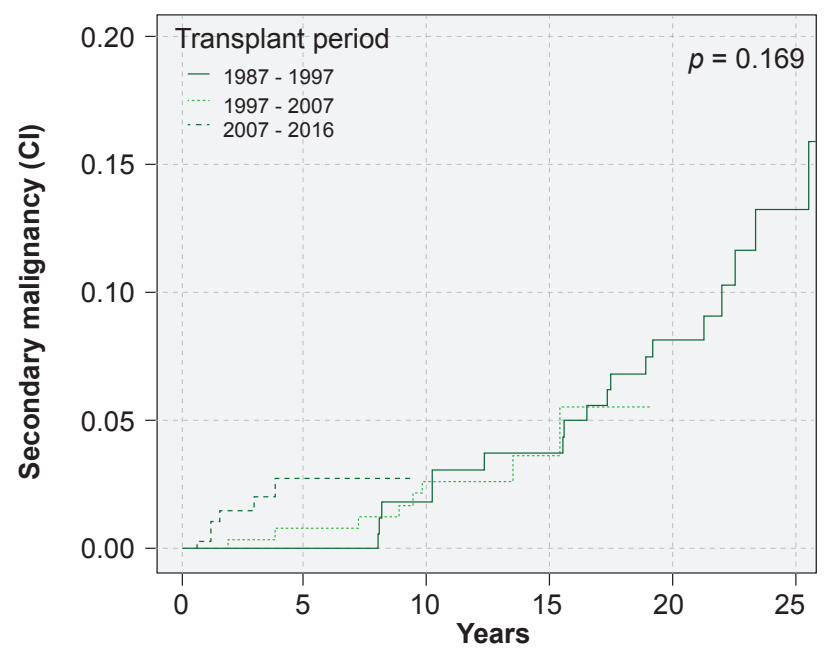

Figure 3 - Cumulative incidence of secondary malignancy by transplant period in overall sample 
Table 2 - Causes of death

\begin{tabular}{|c|c|c|c|c|}
\hline & All patients & $1987-1997$ & $1997-2007$ & $2007-2016$ \\
\hline $\mathbf{n}$ & 310 & 84 & 119 & 107 \\
\hline Relapse/Progression & $138(45 \%)$ & $26(31 \%)$ & $58(49 \%)$ & $54(51 \%)$ \\
\hline HSCT related causes & $169(55 \%)$ & $57(69 \%)$ & $59(50 \%)$ & $53(49 \%)$ \\
\hline Infection & 30 & 7 & 11 & 12 \\
\hline GVHD & 63 & 16 & 27 & 20 \\
\hline VOD & 6 & -- & 3 & 3 \\
\hline Other organ toxicity ${ }^{1}$ & 58 & 28 & 15 & 15 \\
\hline $2^{\text {nd }}$ malignancy & 8 & 4 & 1 & 3 \\
\hline Rejection & 4 & 2 & 2 & - \\
\hline External causes of death ${ }^{2}$ & 3 & 1 & 2 & - \\
\hline
\end{tabular}

${ }^{1}$ Includes: stroke (3), myocardial infarction (1)

2 Includes: suicide (2), accident (1)

GVHD: graft-versus-host disease; VOD: veno-occlusive disease

transplant-related complications decreased significantly over time even though older patients, more advanced disease stages and an increased number of unrelated transplants were performed.

Reduction in NRM has been a consistent finding in recently published studies from several centers that retrospectively compared results obtained over chronologically different periods of allogeneic HSCT activity. Our results are concordant with these reports. ${ }^{27-33}$

Dealing with relapse continues to be a challenge after HSCT as it is now the major cause of treatment failure. New approaches are available such as TKIs targeting Flt3-internal tandem duplication in AML, either alone or in combination with hypomethylating agents. ${ }^{34-39}$ Monoclonal antibodies and antibody-drug conjugates are also being investigated, with blinatumomab being active in relapsed ALL and used either alone or in conjunction with DLI. ${ }^{40}$ Checkpoint inhibitors represent another possible approach for relapse treatment but they may lead to significant GvHD. ${ }^{41,42}$ Genetically engineered $T$ cells are a powerful class of therapeutic agents with several clinical trials showing responses in patients with relapsed, refractory, B-cell malignancies. ${ }^{43,44}$

\section{CONCLUSION}

This study shows the changes and progresses that have occurred in our daily practice of allogeneic HSCT, outside of clinical trials. These developments have allowed us to offer allogeneic transplantation to older patients, patients with comorbidities or more advanced disease and to those without related donors. We observed a statistically significant improvement in NRM over time, despite treating patients with a less favorable prognosis. We believe that allogeneic
HSCT will remain a valuable treatment option for patients with malignant and non-malignant diseases and, with continuous improvement of results, a safer treatment option.

\section{ACKNOWLEDGEMENTS}

We thank all the physicians that during the study period collaborated in the patient care, the nursing staff for their dedicated patient care and the data managers involved in the study. We also thank the Liga Portuguesa contra o Cancro and the Fundação Calouste Gulbenkian for their generous support in setting up the transplant program.

\section{PROTECTION OF HUMANS AND ANIMALS}

The authors declare that the procedures were followed according to the regulations established by the Clinical Research and Ethics Committee and to the Helsinki Declaration of the World Medical Association.

\section{DATA CONFIDENTIALITY}

The authors declare having followed the protocols in use at their working centre regarding patients' data publication.

\section{CONFLICTS OF INTEREST}

The authors declare no potential conflicts of interest with respect to the research, authorship, and/or publication of this article.

\section{FUNDING SOURCES}

The authors received no financial support for the research, authorship, and/or publication of this article.

chimerism, induced specific tolerance and possible anti-leukemic effects. Blood. 1965;25:179-96.

5. Bortin MM. A compendium of reported human bone marrow transplants. Transplantation. 1970;9:571-87.

6. Appelbaum FR. Hematopoietic-cell transplantation at 50. N Engl J Med. 2007;357:1472-5.

7. Lee SJ, Klein J, Haagenson M, Baxter-Lowe LA, Confer DL, Eapen $M$, et al. High-resolution donor-recipient HLA matching contributes 
to the success of unrelated donor marrow transplantation. Blood. 2007;110:4576-83

8. Storb R, Sandmaier BM. Nonmyeloablative allogeneic hematopoietic cell transplantation. Haematologica. 2016;101:521-30.

9. Bacigalupo A, Ballen K, Rizzo D, Giralt S, Lazarus H, Ho V, et al. Defining the intensity of conditioning regimens: working definitions. Biol Blood Marrow Transplant. 2009;15:1628-33.

10. Chaidos A, Kanfer E, Apperley JF. Risk assessment in haematopoietic stem cell transplantation: disease and disease stage. Best Pract Res Clin Haematol. 2007;20:125-54.

11. Petersdorf EW, Longton GM, Anasetti C, Mickelson EM, McKinney SK, Smith AG, et al. Association of HLA-C disparity with graft failure after marrow transplantation from unrelated donors. Blood. 1997;89:1818-23.

12. Pierdomenico F, Ferreira I, Teixeira G, Miranda N, Guimarães A, Fernandez $E$, et al. The role of Campath in HLA-C mismatched unrelated allogeneic transplant: a single center experience. Bone Marrow Transplant. 2011;46:S358.

13. R Core Team. R: A language and environment for statistical computing Vienna: R Foundation for Statistical Computing; 2014.

14. Abecasis M, Gutierrez MJ, Espadinha C, Barbosa AL. Clinical utility of family-directed cord blood storage. Monaco: V World Cord Blood Congress and Innovative Cell Therapies; 2015.

15. Luznick L, O’Donnell PV, Symons HJ, Chen AR, Leffell SM, Zahurak M, et al. HLA-haploidentical bone marrow transplantation for hematologic malignancies using nonmyeloablative conditioning and high-dose posttransplantation cyclophosphamide. Biol Blood Marrow Transplant. 2008;14:641-50.

16. Raiola AM, Dominietto A, Ghiso A, Di Grazia C, Lamparelli T, Gualandi $\mathrm{F}$, et al. Unmanipulated haploidentical bone marrow transplantation and posttransplantation cyclophosphamide for hematologic malignancies after myeloablative conditioning. Biol Blood Marrow Transplant. 2013;19:117-22.

17. Horowitz M. Does matched unrelated donor transplantation have the same outcome as matched sibling transplantation in unselected patients? Best Pract Res Clin Haematol. 2012;25:483-6.

18. Kroger N, Zabelina T, Binder T, Ayuk F, Bacher U, Amtsfeld G, et al. HLA-mismatched unrelated donors as an alternative graft source for allogeneic stem cell transplantation after antithymocyte globulincontaining conditioning regimen. Biol Blood Marrow Transplant. 2009;15:454-62.

19. Jorge AS, Suárez-Lledó M, Pereira A, Gutierrez G, Fernandez-Avilez $F$, Rosiñol L, et al. Single antigen-mismatched unrelated hematopoietic stem cell transplantation using high-dose post-transplantation cyclophosphamide is a suitable alternative for patients lacking HLAmatched donors. Biol Blood Marrow Transplant. 2018;24:1196-202.

20. Michallet $M$, Sobh $M$, Serrier $C, S$ Morisset, Labussière $H$, Ducastelle $S$, et al. Allogeneic hematopoietic stem cell transplantation for hematologic malignancies from mismatched 9/10 human leukocyte antigen unrelated donors: comparison with transplants from 10/10 unrelated donors and human leukocyte antigen identical siblings. Leuk Lymphoma. 2015;56:999-1003.

21. Granier C, Biard I, Masson E, Porcher R, Peffault de Latour R, Robin $M$, et al. Impact of the source of hematopoietic stem cell in unrelated transplants: Comparison between 10/10, 9/10 HLA-matched donors and cord blood. Am J Hematol. 2015;90:897-903.

22. Jabbour E, Kantarjian H. Chronic myeloid leukemia: 2018 updates on diagnosis, therapy and monitoring. Am J Hematol. 2018;93:442-59.

23. Nair AP, Barnett MJ, Broady RC, Hogge DE, Song KW, Toze CL, et al. Allogeneic hematopoietic stem cell transplantation is an effective salvage therapy for patients with chronic myeloid leukemia presenting with advanced disease or failing treatment with tyrosine kinase inhibitors. Biol Blood Marrow Transplant. 2015;21:1437-44.

24. Lee S, Choy SY, Kim SH, Jang EJ, Bang JH, Byeun JY, et al. Prognostic factors for outcomes of allogeneic stem cell transplantation in chronic phase chronic myeloid leukemia in the era of tyrosine kinase inhibitors. Hematology. 2014;19:63-72.

25. Bruggemann M, Gokbuget N, Kneba M. Acute lymphoblastic leukemia: monitoring minimal residual disease as a therapeutic principle. Semin Oncol. 2012;39:47-57.
26. Passweg JR, Baldomero H, Bader P, Basek GW, Bonini C, Duarte R, et al. Is the use of unrelated donor transplantation leveling off in Europe? The 2016 European Society for Blood and Marrow Transplant activity survey report. Bone Marrow Transplant. 2018;53:1139-48.

27. Gooley TA, Chien JW, Pergam SA, Hingorani S, Sorror ML, Boeckh M, et al. Reduced mortality after allogeneic hematopoietic-cell transplantation. N Engl J Med. 2010;363:2091-101.

28. Remberger M, Ackefors M, Berglund S, Blennow O, Dahllof G, Dlugosz $A$, et al. Improved survival after allogeneic hematopoietic stem cell transplantation in recent years. A single-center study. Biol Blood Marrow Transplant. 2011;17:1688-97.

29. Hahn T, McCarthy PL, HassebroekA, Bredeson C, Gajewski JL, Hale GA et al. significant improvement in survival after allogeneic hematopoietic cell transplantation during a period of significantly increased use, older recipient age, and use of unrelated donors. J Clin Oncol. 2013;31:243749.

30. Mateos MK, O'Brien TA, Oswald C, Gabriel M, Ziegler DS, Cohn RJ, et al. Transplant-related mortality following allogeneic hematopoietic stem cell transplantation for pediatric acute lymphoblastic leukemia. 25-year retrospective review. Pediatr Blood Cancer. 2013;60:1520-7.

31. Malard F, Chevalier P, Guillaume T, Delaunay J, Rialland F, Harousseau $\mathrm{JL}$, et al. Continuous reduced nonrelapse mortality after allogeneic hematopoietic stem cell transplantation: a single-institutuion's three decade experience. Biol Blood Marrow Transplant. 2014;20:1217-23.

32. O'Meara A, Holbro A, Meyer S, Martinez M, Buser A, Halter J, et al. Forty years of hematopoietic stem cell transplantation: a review of the Basel experience. Swiss Med Wkly. 2014;144:w13928.

33. Brissot E, Rialland F, Cahu X, Strullu M, Corradini N, Thomas C, et al. Improvement of overall survival after allogeneic hematopoietic stem cell transplantation for children and adolescents: a three-decade experience of a single institution. Bone Marrow Transplant. 2016;51:267-72.

34. Soiffer R, Chen YB. Pharmacologic agents to prevent and treat relapse after allogeneic hematopoietic cell transplantation. Blood Adv. 2017;1:2473-82.

35. Stone RM, Mandrekar SJ, Sanford BL, Laumann K, Geyer S, Bloomfield $\mathrm{CD}$, et al. Midostaurin plus chemotherapy for acute myeloid leukemia with a FTL3 mutation. N Engl J Med. 2017;377:454-64.

36. Battipaglia G, Ruggeri A, Massoud R, Cheikh El, Jestin M, Antar A, et al. Efficacy and feasibility of sorafenib as a maintenance agent for fms-like tyrosine kinase- 3 mutated acute myeloid leukemia. Cancer. 2017;123:2867-74

37. Sid S, Rey J, Charbonnier A, D'Incan, Mohty B, Blaise D, et al. Treatment of post-transplant relapse of FLT3-ITD mutated AML using 5-Azacytidine and sorafenib bittherapy. Clin Lymphoma Myeloma Leuk. 2017;17:2412.

38. Rautenberg C, Hachtkamp K, Dienst A, Schmidt PV, Heyn C, Kondakci $M$, et al. Sorafenib and azacytidine as salvage therapy for relapse of FLT3-ITD mutated AML after allo-SCT. Eur J Haematol. 2017;98:348-54.

39. De Freitas T, Marktel S, Piemontese S, Carrabba MG, Tresoldi C, Messina $\mathrm{C}$, et al. High rates of hematological response to sorafenib in FLT3-ITD acute myeloid leukemia relapsed after allogeneic hematopoietic stem cell Transplantation. Eur J Haematol. 2016;96:62936 .

40. Ueda M, de Lima M, Caimi P, Tomlinson B, Little J, Creger R, et al. Concurrent blinatumomab and donor lymphocyte infusions for treatment of relapsed pre-B-cell ALL after allogeneic hematopoietic cell transplant. Bone Marrow Transplant. 2016;51:1253-55.

41. Haverkos BM, Abott D, Hamadani M, Armand P, Flowers ME, Merryman $\mathrm{R}$, et al. PD-1 blockade for relapsed lymphoma post-allogeneic hematopoietic cell transplantation: high response rates but frequent GvHD. Blood. 2017;130:221-8.

42. Gokbuget N, Canaani J, Nagler A, Bishop M, Kroger N, Avigan D. Prevention and treatment of relapse after stem cell transplantation with immunotherapy. Bone Marrow Transplant. 2018;53:664-72.

43. Dietz AC, Wayne AS. Cells to prevent/treat relapse following allogeneic stem cell transplantation. Hematology Am Soc Hematol Educ Program. 2017;708-15.

44. June $\mathrm{CH}$, Sadelain $\mathrm{M}$. Frontiers in Medicine series: chimeric antigen receptor therapy. N Engl J Med. 2018;379:64-73. 